\title{
RECONSTRUCTION OF PROVIDING A MEDICAL PROFESSION SATISFACTION THAT HAS DISASTER OF PATIENT-BASED INTEREST THE VALUE OF JUSTICE
}

\author{
Edy Sumarwanto \\ A doctor in Muhammadiyah Tulungagung Hospital \\ E-mail : Edysymawanto123@gmail.com
}

\begin{abstract}
Doctors are a noble profession. The doctor's profession requires expertise and thoroughness, because the work of a physician deals with the health and life of a person. Mistakes by doctors can result in disability or death for the patient, so doctors must work with caution. Doctors suspected of malpractice can not simply be criminalized, because no doctor has a bad faith to harm his patients, so that sanctions are imposed should be able to provide justice for doctors and patients.
\end{abstract}

Keywords : Sanctions, Doctors, and Justice

\section{A. INTRODUCTION}

Doctors are medical personnel through medical education, who provide services according to the competencies gained during education, according to service standards (medical, procedures, professional behavior). Doctors in running the profession, bound by various norms and can be given sanctions if it violates. The doctor is a person with a doctor's degree or someone who has a license to practice in the art of healing illness. The term physician in a medical context is all medical professionals with a doctor's degree and a specialist or various other titles. Various professions that can be associated with doctors include doctors, dentists, psychologists / psychiatrists, biomedical scientists, or veterinarians. ${ }^{1}$

The profession of medicine and dentistry is a profession that has nobility because the main task is to provide services to meet one of the basic human needs, namely the need for health. In carrying out its professional duties as a doctor and dentist, in addition to being bound by ethical norms and legal norms, this profession is also bound by the medical discipline norm, which, when enforced, will ensure the quality of service so that the dignity and nobility of the profession is maintained.

\footnotetext{
Fitri, Doctor Profession: Definition, Basic Competency and Duty Doctor, http: // healthy. link / definition-and-the history-the form-profesi-dokter.info, posted on October 30,2014 , accessed on September 16, 2015, at : 10.27 WIB.
}

Professional service is a service provided with a high level of skill, careful, thorough, caring and ethical so that professional actions and behavior become the main basis for doctors and dentists in conducting medical or dental practice to serve patients. Users of medical and dental healthcare services (patients) entrust themselves and their lives to a doctor or dentist in dealing with their health so that adhering to the rules or conditions is a duty of doctors and dentists.

A good medical practice is a practice that is based on standard medical operational procedures, medical service standards, does not deviate from the area of competence, professional conduct, maintain medical ethics and always make informed consent in the act, keep the patient secret, follow the provisions of legality / legislation applicable.

In carrying out the relationship between doctors and patients, the implementation of the relationship between the two is always regulated with certain rules in order to occur harmony in the implementation. In the context of physician and patient relationship, both doctors and patients have their respective roles. This role of role can be analyzed in terms of four basic dimensions: universal, permanent temporary, non-voluntary subordinate and voluntary. ${ }^{2}$

\footnotetext{
2 George M. Foster and Barbara Gallatin Anderson, 2006, Anthropology of Health, translated by Priyanti Pakan Suryadarma dan Meutia F. Hatta Swasono, Universitas Indonesia, Jakarta, page. 123.
} 
A professional is not justified to have a careless attitude about his own professional standards, this inner attitude is very dangerous. Meanwhile, the inner attitude with the consequences that endanger the patient, detrimental to the health or lives of patients in general malpractice of medicine is not addressed or unwanted. Although very rare, it is possible that the will is indeed aimed at adverse effects on the health and life of the patient, for example, euthanasia Article 344 of the Criminal Code or abortion outside medical indication, Article 347, Article 348 of the Criminal Code. ${ }^{3}$

The medical discipline norm ties doctors and dentists in applying their scholarship when practicing medicine, related to doctor's relationship with the patient. Implementation and enforcement of new disciplinary norms can be said to be active when performed in the conduct of medical practice.

Basically the medical discipline is the discipline of medical doctors and dentists to perform medical practices in accordance with standard operating procedures (spo), standard medical services, not deviate from the competence it has to enter the field of other doctors although it can do so except in an emergency. Violation of the discipline of the medical profession, a physician / dentist may be referred to the Indonesian Medical Disciplinary Council for examination, investigation, trial, summoning witnesses, examination of evidence instruments, listening to expert information up to termination by disciplinary council enforcement of wrong or not a doctor / dentist. MKDKI is a part of the Indonesian medical council responsible to the President of the Republic of Indonesia. Sanctions for violations of this professional discipline, doctors or dentists may be given written warnings, revocation of practice licenses or re-education (reschooling). The weight and severity of sanctions given to doctors or dentists based on the level of medical discipline violations committed.

Doctors and dentists who are proven to violate the norms of medical discipline can be disciplined

\footnotetext{
3 M. Lukman, Perlindungan Hukum Atas Praktik Kedokteran (on-line), diposting pada dihttp://lukman-el-kahfi.blogspot. com/2007/12/perlindungan-hukum-atas-praktik. html. posted on 10 July 2011, acceed on 17 September 2015, at : 9.05 WIB.
}

according to the level of their mistakes. Medical disciplinary sanctions are regulated in Article 69 paragraph (3) of Law Number 29 Year 2004 regarding Medical Practice, namely:

a. Written warning;

b. Recommendation for revocation of registration letter or license of practice; and / or

c. Obligation to attend education or training in medical or dental education institutions.

Some forms of sanctions are deemed not to provide benefits and justice, especially for the profession of doctors.

If a patient feels aggrieved by the practice of medicine can make a complaint to MKDKI against a doctor / dentist. Complaints to MKDKI do not diminish the patient's right to report such a doctor of alleged criminal acts to the authorities and or sue a civil suit to court. This is as regulated in Article 66 of Law Number 29 Year 2004.

From the provisions of Article 66 of Law Number 29 Year 2004, it can be concluded that a doctor and dentist who commits a disciplinary offense can be complained to MKDKI. Complaints to MKDKI do not deprive everyone of the right to make their losses to court (the legal domain). This resulted in a doctor or dentist can get double sanctions, even triple can be revoked a license to practice or follow the reschooling as well as getting legal sanctions both civil and criminal as well as sanctions of ethics by professional organizations. Of course it is detrimental to the profession of doctors and dentists as well as other interested parties such as hospitals that employ the doctors / dentists, the public, and the government. This penalty is not satisfying the sense of justice. Whereas the purpose of the law is to provide a sense of justice. So what is the implementation of sanctions in the medical profession that harms the interests of the patient has not been fair. How are the disadvantages of implementing sanctions in the medical profession that harm the interests of patients today. How does the reconstruction of sanctions in the medical profession adversely affect the interests of patients based on the value of justice? 


\section{B. DISCUSSION}

1. Implementation of sanctions on the medical profession that harms the interests of the patient is not yet fair;

In the Indonesian Doctor's Oath Pronunciation (LSDI) and the Indonesian Medical Code of Ethics (KODEKI) have been outlined the behavior or actions that are reasonable and unfit for a doctor to perform his profession. However, there are some doctors who commit ethical violations, even ethical and legal violations (ethicolegal), especially in the societies that are experiencing various crises lately, and as sanctions provided by superiors or by professional organizations are caused between other by the unclear boundaries between may and should not, between a reasonable or not worth a doctor to a patient, peers, or the general public. This is the difference between ethics and law. The law is more assertive and more objective indicates things that are illegal so that in case of violation can be processed in accordance with applicable law. ${ }^{4}$

Violations against the points of the Indonesian Doctor's Oath Pronunciation and the Indonesian Medical Code of Ethics are those that are purely ethical violations and others that are both ethical and law violations. Violation of ethics does not necessarily mean a violation of the law, otherwise the breach of the law is not always a violation of medical ethics.

Sanctions given to doctors or dentists who violate medical norms are regulated in detail in the Indonesian Medical Code of Ethics compiled by the Indonesian Doctors Association), while the ethical norms of dentistry are regulated in the Indonesian Dentistry Code of Ethics compiled by the Dentists Association Indonesia.

Violations against ethical norms are not threatened by law, but are punished by society ${ }^{5}$ with moral sanctions and social sanctions. Moral sanctions can not be imposed. Examples

4 M. Jusuf Hanafiah dan Amri Amir, Etika Kedokteran dan Hukum Kesehatan, Edisi 4, Penerbit Buku Kedokteran EGC, Jakarta, 2007, page. 174.

5 As'ad Sungguh, Kode Etik Profesi tentang Kesehatan: Kode Etik Kedokteran Indonesia dan Pedoman Pelaksanaan Kode Etik Kedokteran indonesia, Sinar Grafika, Jakarta, 2014, page. 39 of sanctions in the field of morals are an uneasy conscience. Acts of violation of ethics also result in social sanctions. Social sanctions can be a reprimand from social leaders to the exclusion of social life.

Sanctions given to doctors or dentists who violate legal norms by doctors or dentists result in the threat of punishment. The punishment is generally dropped by the judge after the question becomes a court case and is proven to be a violation of the law.

In the medical world of course we know of the Organization of Indonesian Doctors Association and Association of Dentists Indonesia. Within the organization there is a special body established to conduct guidance, supervision and assessment in the implementation of medical ethics and then have the obligation, among others, to fight for medical ethics to be upheld in Indonesia called the Medical Ethics of Honor Council. So if there is a violation of ethical norms of medicine and dentist then MKEK is authorized to judge. In addition to MKEK as an institution authorized to supervise the implementation of medical ethics, there are also other institutions authorized to uphold the medical discipline, namely MKDKI.

The Honorary Council of Indonesian Medical Discipline (MKDKI) is the institution authorized to determine whether there is a mistake by doctors and dentists in the application of medical and dental disciplines. The Honorary Council of Indonesian Doctors (MKDKI) was established to enforce the discipline of doctors and dentists in the implementation of medical practice, namely the enforcement of rules and or the application of medical scholarship in the implementation of medical services that should be followed by doctors and dentists. Unfortunately, the existence of MKDKI as an institution of discipline of medical discipline is currently not widely known by the general public even many doctors who do not understand what it is MKDKI. ${ }^{6}$ According to Ali Bazaid that

\footnotetext{
https://m.tempo.co/read/news/2013/12/16/kasus-dokterayu-banyak-dokter-tak-mengerti-mkdki., diposting pada Senin, 16 Desember 2013, pukul : 21.22 WIB, diakses pada Jumat, 22 Juni 2016, pukul : 20.00 WIB.
} 
the role of MKDKI is not widely known to the public. Whereas the MKDKI institution is a vital institution in resolving the dispute that disputes the doctors profession.

The case of alleged malpractice of medicine is not easily resolved according to the criminal law, in which case it enters various legal and medical considerations which are often difficult to find in common opinion, both from law enforcement circles and among physicians. Although the last from the corner of the law in the end there is the legal certainty.

Legal certainty must be respected by all parties, and it can not be reappointed as a legal matter of equal incidence. For the purposes of the development of legal science the final decision may be examined from the point of legal academician, and not at all have any effect on the decision that has been fixed. However, legal review of judgments may be used in subsequent cases.

In any case of medical malpractice allegations concerning Article 359 of the Criminal Code, the core of the matter is on the death penalty of the patient and on whether or not the physician's legal obligation is violated in the event of death. From a legal point of view it is not easy to solve and answer two basic issues.

This situation causes the difficulty of obtaining genuine justice in the verdict of medical malpractice cases. The legal certainty of a fixed decision is not always consistent with true justice and legal justice.

Medical science is a specific science that will be understood correctly by medical professionals. Law enforcers (police) will not be able to understand fully and thoroughly without any medical profession education. Therefore, in every legal process both criminal and civil becomes an absolute obligation to present medical experts. Because the internal rules of both medical ethics and medical discipline, and the law has a different position in upholding alleged medical errors. The Government itself has given full authority to the MKDKI institution to break every violation of medical discipline. This is in line with the suggestion that the meaning of justice is to treat equally the same and treat differently to two completely different things.

In assessing whether or not there is a mistake in the medical service of a physician, the medical service must contain unlawful properties. The unlawful nature is caused by a number of possibilities, among others: ${ }^{7}$

a. Violation of Medical Professional Standard;

b. Violation of Standard Operating Profession;

c. Violations of the law, such as practices without STR or SIP;

d. Violation of the Medical Code of Ethics (KODEKI);

e. Violation of general principles of medicine;

f. Violation of public decency;

g. Medical practice without informed consent;

h. Therapy does not meet the patient's medical needs;

i. Therapy does not comply with informed consent and so on.

For that in carrying out the task of his profession, a doctor should always pay attention to the element of prudence, so as not to get caught in a medical dispute with the patient. Given the existence of MKEK and MKDKI not yet widely known to the public, will complicate the profession of doctors / dentists to escape from the law.

\section{The disadvantages of imposing sanctions on medical professions that harm the interests of patients today;}

The lack of public knowledge about medical dispute resolution has a significant effect on the administration of sanctions in the medical profession, the effect of which affects the harm to doctors in particular and the public and the government in general.

The general public has not understood the differences in the three rules / norms

7 Adami Chazawi, 2016, Medical Malpractice, Sinar Grafika, Jakarta, page. 5-11. 
I norms in the medical profession, so the community considers that if a patient is harmed by the practice of a doctor / dentist then automatically the doctor / dentist has committed a crime. Though not, because the violation of ethical norms, norms of discipline or even legal norms can not necessarily be categorized as a crime as mentioned in Book II and Book III of the Criminal Code.

If communities and governments understand well the difference between ethical norms, disciplinary norms and legal norms then, actions taken in providing sanctioned policies will work well, surely, benefit and fair. The imposition of sanctions on the medical professions that have not been justice because the government in this case law enforcers do not heed the differences of the three norms. To enforce justice in the sanction of ethical violations and / or medical discipline, it is necessary to understand the differences between these three norms. People should not confuse the three norms. In addition, the participation of law enforcement and government in this case is necessary. Participation may be provided in the event of any complaint of ethical violation and / or medical discipline to the police (court / police) must submit the file to MKEK for violation of ethical norms and to MKDKI institution for medical discipline violation. Because cases that fall within the category of violation of ethical norms or medical discipline are not the jurisdiction of the court to decide.

The weakness of the implementation of sanctions in other medical professions is related to the provision of Article 66 Paragraph (3) of Law Number 29 Year 2004. In the Article it is stipulated that: "The complaints referred to in paragraphs (1) and (2) do not eliminate any right people to report any alleged criminal acts to the authorities and / or to sue for civil injury to the court ". From these provisions as if not provide clear legal certainty. In carrying out its professional duties, a doctor and dentist is bound to three norms norms of ethics, discipline and law. The existence of the article seems to ignore the differences of the three norms. In fact, the provisions of Article 66 paragraph (3) seem to give space for the existence of double sanction or even triple (akumulation sanction) to doctors who commit violations regardless of what type of violation is violated. This led to the assumption that the legislators did not heed the internal provisions of the medical profession.

From the provision of Article 66 paragraph (3), it can be deduced that a doctor / dentist who commits an offense can be reported successively to MKEK and / or MKDKI at the same time can be complained for civil or criminal to the court. As a result, an infringing physician will get a mild sanction in the form of either SIP (Surat Izin Praktik) or STR (Registration Certificate) either temporarily or permanently sanctioned by civil or criminal sanction. If this happens of course the doctor becomes one of the disadvantaged because the right doctor as a medical personnel will be violated. Whereas the Medical Practice Act is intentionally made to ensure doctors I dentists feel safe in carrying out their professional duties.

One of the weaknesses of the implementation of sanctions on the violation of the medical profession is the application of the formal rules contained in Article 66 paragraph (3) of the Medical Practice Law. The conduct of Article 66 Paragraph (3) has not provided a sense of justice for doctors in particular and society in general. This article tends to ignore the existence of three rules of value in the medical world, other than that this Article does not seem to notice the existence of MKDKI and MKEK institutions in the medical profession. Though both institutions have a vital role in solving problems related to medical profession violations.

Some weaknesses in sanctioning the medical profession abuses. The weaknesses among others are:

a. Violations of medical ethics and violations of medical discipline are mixed up in violation of the law. The community considers the violation both of them should be complained to the 
police, but not so. This resulted in the imposition of sanctions for violations of the medical profession has been wrongly targeted. Violation of ethics that should be complained to MKEK IDI / MKEK PDGI and violation of medical discipline that should be to the institution MKDKI-KKI actually complained to the court. This has a disastrous effect on doctors / dentists both materially and immaterially;

b. Giving witnesses to the medical profession has not been paying attention to social interests. The sanction given only concerns the patient's interest (the claimant) without noticing the public interest in general;

c. The nature of the sanction in violation of the medical profession is the accumulation sanction. Complaints to MKEK IDI / MKEK PDGI and MKDKI$\mathrm{KKI}$ do not deprive everyone of the right to file court to civil or criminal court. This has the effect of double sanctions for the medical profession. These double sanctions do not provide the value of benefit and the value of justice. Should sanction for violation of the medical profession prioritize the fulfillment of the value of justice and the value of expediency is not merely just prioritize the value of legal certainty alone.

3. Reconstruction of sanctions to medical professions that harm the interests of patients based on fairness values.

a. Reconstruction Philosophy / Values;

1. The nature of law enforcement relates to issues of justice, certainty and social benefit. Prophetic justice should serve as a basis for sanctions for violations of the medical profession, for prophetic justice is certainly in line and synergistic with other values of justice, especially substantive justice, which takes into consideration the substantive values of its judgments, not solely on procedural justice. Thus, the issue of improper sanctions imposed on the medical profession violation will be resolved. By realizing this value of prophetic justice will have an impact on the concept of balanced legal protection between patients, doctors, hospitals and government.

2. Reconstruction of the Law The need for reconstruction / renewal of several articles in the Law 29 Year 2004, among others:

1) Article 3 Sub-Article a of Law 29 Year 2004

a) Before The regulation of medical practice aims to:

a. Providing protection to patients;

b. Maintain and improve the quality of medical services provided by doctors and dentists; and

c. Providing legal certainty to the public, doctors and dentists.

b) After

The regulation of medical practice aims to:

a. Provide protection to patients, doctors or dentists and hospitals;

b. Idem;

c. Idem.

2) Article 66 paragraph (3) of Law Number 29 Year 2004

a) Before

(1) Anyone who knows or interests are harmed on the actions of a doctor or dentist in carrying out medical practice can complain in writing to the Chairman of the 
Honorary Council of Indonesian Medical Discipline.

(2) Complaint must at least contain:

a. Identity of claimant;

b. The name and address of the doctor or dentist's office and the time of action taken; and

c. The reason for the complaint.

(3) Complaintsasreferred to in paragraphs (1) and (2) shall not diminish the right of any person to report any alleged criminal acts to the authorities and / or sue for civil damages to the court.

a) After

1. Idem;

2. Idem;

3. In the case of the MKDKI, if the complaint as referred to in paragraphs

(1) and (2)

contains

elements

of criminal offense / civil loss, the injured party shall report to the police and / or take the civil liability to court.

3) Article 69 paragraph (3) of Law Number 29 Year 2004

a) Before

(1) The Decision of the
Indonesian Medical

Discipline Honor Board binds doctors, dentists, and the Indonesian Medical Council.

(2) The decission as referred to in paragraph (1) may be declared not guilty or disciplinary sanction.

(3) Disciplinary sanctions as referred to in paragraph (2) may be in the form of:

a. Written warning;

b. Recommendation for revocation of registration letter or license of practice; and / or

c. Obligation to attend education or training in medical or dental education institutions.

e) After

(1) Idem;

(2) Idem;

(3) Disciplinary sanctions as referred to in paragraph (2) may be in the form of:

a. Written warning;

b. Making scientific papers;

c. Re-therapy;

d. Assigned in another area;

e. Teaching at educational institutions;

f. A t te nding education or training in medical ordental education institutions; 
g. Conducting social activities;

h. Conducting $\mathrm{sc}$ i e n t if i c research;

i. Became another physician's assistant;

j. Conducting health promotion to the community;

k. Undertaking internships;

I. Limitations of doctor's clinical authority.

\section{CONCLUSION}

Implementation of the sanction of medical profession has not been fair because of the existence of MKEK (Medical Ethics Council of Honor) and MKDKI (Indonesian Medical Discipline Honor Board) which has not been widely known by the society resulted in complaint of ethical violation and medical discipline is wrong address.

The disadvantages of implementing the sanction of the medical profession are the lack of public knowledge about medical dispute resolution. Understanding disciplinary norms and legal norms is vital for both physicians, the public, law enforcers and the government. Violations against the norm each have different consequences. This is one of the reasons for the imposition of sanctions on the medical profession has not fulfilled the value of justice. The weakness of the implementation of sanctions in other medical profession is related to the provisions of Article 66 Paragraph (3) of Law Number 29 Year 2004. The provisions of the Article seem to give room for the existence of double sanction or even triple (akumulation sanction) to doctors who do infringement regardless of what kind of violation violated.

Reconstruction of sanctions to medical professions that harm the interests of patients on the basis of justice values, including the reconstruction of the value of medical sanctions that harm the interests of patients by providing balanced legal protection between patients, doctors / dentists and hospitals based on prophetic justice, and legal reconstruction in Article 3 Sub-Article a, Article 66 Paragraph (3) and Article 69 Paragraph (3) of Law Number 29 Year 2004.

Socialization of the existence of MKDKI is important to do. It can provide knowledge to the public about the function and authority of MKDKI in resolving medical disputes between doctors and patients;

There is a need for reconstruction of disciplinary sanction in the reconstruction of Article 69 paragraph (3) of Law Number 29 Year 2004 which is adapted to the concept of prophetic justice.

Establish an Honorary Council of Indonesian Medical Disciplines at the provincial and district / city levels, so that medical dispute resolution can proceed fairly, effectively and efficiently.

\section{BIBLIOGRAPHY}

Adami Chazawi. 2016. Medical Malapraktik, Sinar Grafika, Jakarta.

As'ad Really, the Code of Professional Ethics on Health: The Indonesian Medical Code of Conduct and Code of Conduct for the Indonesian Medical Code of Conduct, Sinar Grafika, Jakarta, 2014.

George M. Foster and Barbara Gallatin Anderson, Anthropology of Health, translated by Priyanti Pakan Suryadarma and Meutia F. Hatta Swasono, University of Indonesia, Jakarta, 2006.

M. Jusuf Hanafiah and Amri Amir, 2007. Medical Ethics and Health Law, Issue 4, Medical Book Publishers EGC, Jakarta.

Soerjono Soekanto. 1988. Sociology Approach to Law, Bina Aksara, Jakarta.

Zamroni, Development of Introduction to Social Theory, Tiara Yoga, Yogyakarta. 
Fitri, Profesi Dokter: Definisi, Kompetensi Dasar dan Tugas Dokter, http://sehat.link/definisidan-sejarah-terbentuknya-profesi-dok ter.info

https://m.tempo.co/read/news/2013/12/16/kasus-dokter-ayu-banyak-dokter-tak-mengerti-mkdki., posted on Monday, 16 December 2013

M. Lukman, Perlindungan Hukum Atas Praktik Kedokteran (on-line), diposting pada dihttp:// lukman-el-kahfi.blogspot.com/2007/12/ perlindungan-hukum-atas-praktik. html. posted on 10 July 2011 , 